\title{
Utilization of Waste for Energy Generation in Clinker Production: Environmental Perspective
}

\author{
Fatma Didem Tunçez \\ Energy Management Department, University of KTO Karatay, Konya-42020, Turkey. \\ Corresponding Author Email: didem.tuncez@karatay.edu.tr \\ Received 08 September 2020, Revised 10 December 2020, Accepted 14 December 2020
}

\begin{abstract}
Meeting the increasing energy need from fossil fuels such as coal, oil and natural gas caused the rapid depletion of natural resources. In a world where the need for energy is constantly increasing and resources are getting scarce; it is necessary to ensure the sustainability of energy. Clinker production is a process which require high amount of energy in manufacturing industry. The fact that energy is mostly obtained from coal, which is a non-renewable fuel, puts the future of the sustainability of cement production at risk. Alternative fuel usage plays the most important role in achieving more than one goal, such as protecting natural resources and utilization of waste. In this study, data was obtained from Turkish cement factories which used waste for fuel generation in clicker production in year 2017. The data was evaluated and amount of coal that could be saved annually was calculated. Results revealed that a10934.573 TJ of energy was obtained from the use of waste for alternative fuel in 2017 in Turkey thus, it is demonstrated that 918871 tons of nonrenewable fuel-lignite coal could be preserved.
\end{abstract}

Keywords: Cement, Alternate Energy, Fuel from Waste, Coal, Clinker Production.

\section{Introduction}

At the present time, the need for energy is increasing due to the developing technology and increasing production with growing population. Increased energy requirement leads to the rapid depletion of non-renewable fossil resources. Energy production based on fossil sources brings problems such as air pollution and climate change, depleting of natural sources in the world. After the invention of cement as a binder, the need for cement increased with the improvement of construction technologies [1]. Therefore, concrete production in the world is one of the leading products in the world. Turkey's cement production was reached as 80.5 million tons in 2018 [2]. The cement manufacturing sector is in the forefront of natural energy-intensive sectors. This value is $849 \mathrm{kcal} / \mathrm{kg}$ for preheated furnaces and 803 $\mathrm{kcal} / \mathrm{kg}$ for pre-calcination kilns [3].

The highest share in the cost structure of the cement sector is energy cost. The processes that use energy intensively in cement production are defined as raw material crushing, blending, raw meal grinding, clinker firing and cement grinding processes.

Fuel oil, coal, natural gas, petroleum coke, anthracite or their mixtures are used in various ratios for burning in the cement rotary kiln. The fuel is fed from the burner pipe into the kiln. The chemical and physical reactions continue to occur with increasing temperature. 
All materials are combusting with fossil fuels in kiln, so ash comes from coal reacts like raw material for clinker in the rotary kiln and no residue is formed from cement process [4]. The semi-manufactured product is called clinker $[5,1,6]$. High process temperature is required in the clinker sintering process. As well as the global trend, energy costs in cement production is increasing. Therefore, cement producers have started to look for alternative fuels instead of coal and other fossil fuels for the sustainable economy [7]. The recovery of waste as energy in the cement industry has been on the agenda all over the world [8]. This new approach to the disposal of waste while recovering energy from waste has become one of the environmental goals of the cement industry [9].

It is impossible for a country to be termed as a developed having high amount of waste piled-up, even if the problem in question is explained as a result of industrialization. Efforts towards developing economies through industrialization, is one factor that leads to an increase in the amount of waste, and a negatively impact nature and cause depletion of non-renewable natural resources. Therefore, its responsibility of all societies and sectors to achieve a balance between development and ecology.

Furthermore, the cataleptic use of wild storage and disposal methods for waste, accumulation, collection and transportation of waste cause extra costs and leave negative effects on the environment. In the past, the thought of being seen the waste as garbage, which contain great threats to human health and environment, goes down in history. The recovery of waste as energy is an environmentally friendly activities which strengthens the country's economy and protects environment from the waste [10-13]. According to the waste hierarchy natural resources will be protected. And waste will be recovered by using waste in cement plants rather than underground storage. In addition to that, the concept of zero waste in the industry will be implemented by recovery of waste. Wastes from industrial enterprises constitute a unilaterally manner industrial symbiosis model which is an innovation in zero waste approach with the use in cement plants [13].

Alternative fuels are used as energy source in cement industry. A $30 \%$ of the total energy consumed in the cement industry in Europe was supplied from waste, thus preserving approximately 11 million tons of coal as natural resource [14]. Alternative fuels are derived from the mixtures of hazardous industrial waste like paint sludge, solvent, wood, plastic, textiles, rubbers, drilling mud, oil refining waste, liquid fuel waste, pulp sewage, sewage sludge, end-of-life tires, municipal waste, spent waxes and fats [1516]. Calorie-rich wastes are preferred as fuel in cement industry except untreated municipal waste nuclear waste, battery and accumulator, hospital waste [17-18].

Process of plant would able to use waste instead of coal requires some modifications. The waste must be passed through various preparatory stages before being fed into the kiln and in order to obtain the maximum benefit from the waste. Waste is treated by some processes as classification, separation of metals, shredding, and moisture and calorie adjustment. Therefore, there is a need to prepare the waste outside the cement plants and prepare them for incineration. Subindustry branches have been established to facilitate for easy-feeding of waste to cement kilns with the efforts to increase the use of waste. An alternative solid type obtained from combustible material after separation, shredding of domestic or industrial solid waste, recoverable materials (plastic, glass, metal, etc.) is called refuse-derived fuel (RDF). The RDF production facilities prepare 
ready-mix waste for cements [19]. This fuel with high calorific value- optimum moisture is used as fuel in cement plants and energy production facilities. RDF with as specialized calorific value, moisture and size prepared according to the cement plants, is an efficient type of waste mixture that is easily fed [20].

The RDF is used energy source by coprocessing in cement plants. Co-processing means burning the waste with conventional fuel. Waste accepted to cement plants can be RDF or directly industrial or domestic waste which has not been treated before. The alternative fuels derived from waste is pretreated such as shredding, drying, sorting, crushing, blending, homogenization before feeding to kiln. Co-processing plant must have special units for the management of accepted waste such as waste reception unit, temporary storage, pre-treatment unit, odor treatment system, waste feeding conveyors and air supply systems, stack gas measuring devices and monitoring systems and flue gas treatment units. All unit devices, machines, conveyors must be ex-proof material against fire hazard. All units must have fire protection and extinguishing measures like extinguishing water pool, foaming extinguishing chemical stock. The waste reception unit and temporary storages should be equipped with odor control, surface water drainage system. Personnel work in handling, loading of waste in plant must be educated on occupational safety about waste and environmental pollution control. Periodic re-certification about waste should be done for waste workers. Documentation must be written and implemented according to ISO 9001/14001/18001 management systems. Emergency and spill response plans must be done for waste stock and feeding areas [21].

The environmental authorities and cement plants are as solution partners for the disposal of hazardous waste for energy recovery due to the rotary kiln's properties in waste combustion.

The clinker kilns have high temperature, oxidizing and alkaline atmosphere [22-24]. The combustion chamber of the kiln has a long retention time (more than $8 \mathrm{sec}$ ) and is available for completing the combustion of waste [24]. The gas resulting from the combustion of the waste is burned for more than $2 \mathrm{sec}$ at a temperature above $850^{\circ} \mathrm{C}$. Co-processing of waste does not increase the burden of existing kiln emission. It is also advantageous if the temperature inside the cement kiln is higher than $1100^{\circ} \mathrm{C}$ for the recovery of waste containing halogenated organic substances [17]. The share of coal in the conventional fuels used in the cement sector is higher than the other fossil fuels. Environmental impacts arising from coal extraction activities will be prevented by using waste instead of coal. The coal quarries are businesses with significant environmental impacts. There are negative impacts such as dust, noise and vibration during coal extraction. The flora of the region is disappearing, and its fauna is suffering greatly. The agricultural and residing areas around the quarry are affected negatively by the dust fall in field. It is unlikely that the land that has been damaged during or after mining activities and damaged natural balance can be reinstated in various ways after the operation. The rehabilitation of quarry is very difficult and costly after the coal reserve is exhausted. Preserving natural resources will be a goal in ensuring sustainable environmental principles by using waste instead of coal in cement industry. Reducing the carbon footprint by the use of alternative fuels in the cement industry is one of the advantages of subject [25-26]. $\mathrm{CO}_{2}$ emissions per ton of clinker while using petroleum coke is about 0.53 ton of $\mathrm{CO}_{2}$, while $\mathrm{CO}_{2}$ emissions from RDF consumption is about 0.31 ton of clinker [3,21,27]. Prevention of greenhouse gases from landfills 
and traditional incinerator is also an advantage by using waste instead of burying underground [28-30]. Co-processing has no effect on increasing the pollutant load in the flue gas like incinerating waste because of the oxidizing atmosphere in rotary kiln [23]. High temperature at the main burner can completely destroy unwanted organic substances present in the input material, that is a great environmental advantage. Parameters that should be measured in the plants where waste is used in according to the IPPC Directive [21]. The periodic controls of emission limit values of cement plants are as follows: emission limit values for dusts, sulfur dioxide $\left(\mathrm{SO}_{2}\right)$ nitrogen oxides (NOx) and other nitrogen compounds, and other sulfur compounds, metals and hydrogen fluoride (HF), total organic compounds (TOC) including volatile organic compounds (VOC), hydrogen chloride $(\mathrm{HCl})$, polychlorinated dibenzo-p-dioxins and dibenzofurans (PCDDs and PCDF), carbon monoxide (CO).

Combustion plants must obtain approval and a license from the environmentally competent authority of the country in which they are located. The cement plant applied for the license must make trial burn testing regarding the use of waste. According to a waste menu which is generated from the waste to be used in the plant, flue gas emission measurement is obligatory two full days after the waste feeding starts during the trial burn. In case a trial burn testing is required, the following simple rules and regulations should be applied for the testing procedures: dust, $\mathrm{SO}_{2}, \mathrm{NOx}$, and $\mathrm{VOC}$ are measured $\mathrm{HCl}, \mathrm{NH}_{3}$, benzene, PCDDs/PCDFs and heavy metals are too.

The most important issue of cement producers is to have no significant effect on the clinker quality by using alternative fuels. Heavy metal which comes from waste will have no impact on the quality of cement [21].
Nevertheless, plants should establish waste acceptance procedure, all the waste to be entered in input control analyzes (calorific value, chemical composition, humidity) must be visually checked (leakage, etc.) and weighed equipped with radiation meterweighbridge $[5,24]$.

Table 1. European Waste Code, European Waste Definition [31].

\begin{tabular}{ll}
\hline Code & \multicolumn{1}{c}{ Defination } \\
1 & $\begin{array}{l}\text { Wastes resulting from exploration, mining, quarrying, and } \\
\text { physical and chemical treatment of minerals }\end{array}$ \\
2 & $\begin{array}{l}\text { Wastes from agriculture, horticulture, forestry, hunting and } \\
\text { fishing, food preparation and processing }\end{array}$ \\
3 & $\begin{array}{l}\text { Wastes from wood processing and the production of panels } \\
\text { and furniture, pulp, paper and cardboard }\end{array}$ \\
4 & Wastes from the leather, fur and textile industries \\
5 & $\begin{array}{l}\text { Wastes from petroleum refining, natural gas purification } \\
\text { and pyrolytic treatment of coal }\end{array}$ \\
6 & Wastes from inorganic chemical processes
\end{tabular}

$7 \quad$ Wastes from organic chemical processes

Wastes from the manufacture, formulation, supply and use of coatings (paints, varnishes and vitreous enamels), adhesives, sealants and printing inks

10 Wastes from thermal processes

11 Wastes from chemical surface treatment and coating of metals and other materials; non-ferrous hydrometallurgy

12 Wastes from shaping and physical and mechanical surface treatment of metals and plastics

13 Oil wastes and wastes of liquid fuels (except edible oils, and those in chapters 05,12 and 19)

15 Waste packaging, absorbents, wiping cloths, filter materials and protective clothing not otherwise specified

16 Wastes not otherwise specified in the list

17 Construction and demolition wastes (including excavated soil from contaminated sites)

Wastes from waste management facilities, off-site 19 wastewater treatment plants and the preparation of water intended for human consumption and water for industrial use

Municipal wastes (household waste and similar 20 commercial, industrial and institutional wastes) including separately collected fractions 


\section{Methodology for Case Study of Turkish Cement Factories}

Industrial and domestic waste is used as alternative fuel in 35 of the 54 integrated cement factories in Turkey, scope of the permissions granted by the Ministry of Environment and Urbanization. Cement plants can use waste for $40 \%$ use of their thermal power generation capacity in Turkey [32]. But none of the factories currently has reached this capacity. On average, waste usage is around $4.5 \%$ [33].

If the clinker production facility has required features, it can obtain a license from the Ministry of Environment to use waste instead of non-renewable fuel coal and can bring a sustainable approach to its production. In this study, cement plants were run throughout a year on various types of wastes in Turkey in real scale. European waste codes (Table 1) were used for various waste types and Calorific values of each waste type was obtained. Amount of coal for equivalent energy obtained from waste was calculated and amount of coal that could be preserved was estimated. Each factory accepts nonhazardous and hazardous wastes from the market from its own supply chain. The wastes entered the factories in accordance with the procurement procedures and in accordance with the environmental legislation and analyzed by taking samples from each shipment. Samples are evaluated for net calorific value using bomb calorimeters according to CEN/TS 16023 Characterization of Waste - Determination of Gross Calorific Value and Calculation of Net Calorific Value standard.

\section{Results and Discussion}

The amount of energy recovered in cement plants in Turkey is calculated by amounts and calorific value of co-processed waste. The calorific values of the waste were determined in the quality control laboratories of the factories. The definitions of international waste code groups were given in Table 1. Calorific values, amount of waste and international waste codes are given in Table 2.

Natural resources which cannot be renewed are preserved by using waste instead of conventional fuel. The amount of coal corresponding to the energy recovered in 2017 was investigated. The calorific value specified in the Intergovernmental Panel on Climate Change (ICCP) Guideline for lignite coal was used to calculate the amount of coal preserved.

The amount of lignite was calculated by using IPCC guide to achieve the same amount of energy with the waste used in cement industry;

$$
\begin{aligned}
& \begin{aligned}
& \text { Lignite }=10934,573[\mathrm{TJ}] / 11.9\left[\mathrm{TJ} \cdot \mathrm{Gg}^{-1}\right] \\
&=918,871 \mathrm{Gg} \times 10^{3} \text { ton. } \mathrm{Gg}^{-1}=918871 \text { tons } \\
& \quad \text { Calorific Value of Lignite }=11.9
\end{aligned} \\
& \text { TJ.Gg }{ }^{-1} \text { [34]. }
\end{aligned}
$$

This is equivalent to the energy that can be obtained by burning 918871 tons of lignite. Co-processing wastes in clinker kilns provided 918871 tons of savings in lignite in 2017. Thus, the energy costs could be decreased which reduces the production costs. Furthermore, co-processing of waste contributes to the national economy by not establishing new waste incineration plant and waste landfill investments.

Over the years mankind has learned various ways to dispose-off waste. Waste has been buried, space is required for storage, and greenhouse gases are generated from large waste storage areas. Incinerated waste may cause air pollution and residue had been formed as results of combustion. Therefore, use of waste as alternative fuel in cement production have benefits in terms of 
environment as well. Waste in cement plants co-processed under better conditions than the waste incineration conditions specified in the legislations.
Coal resources are preserved as natural resources and the environmental pollution that occurs during the extraction and transportation of the coal are prevented by co-processing the waste in plants.

Table 2. The waste co-incinerated at cement factories in 2017 and the energy obtained [33].

\begin{tabular}{|c|c|c|c|c|c|c|c|c|}
\hline $\begin{array}{l}\text { European } \\
\text { Waste Code }\end{array}$ & $\begin{array}{l}\text { Amount } \\
\text { (ton) }\end{array}$ & $\begin{array}{l}\text { Average } \\
\text { Calorific } \\
\text { Value (TJ/Gg) }\end{array}$ & $\begin{array}{l}\text { European } \\
\text { Waste Code }\end{array}$ & $\begin{array}{l}\text { Amount } \\
\text { (ton) }\end{array}$ & $\begin{array}{l}\text { Average } \\
\text { Calorific } \\
\text { Value (TJ/Gg) }\end{array}$ & $\begin{array}{l}\text { European } \\
\text { Waste Code }\end{array}$ & Amount (ton) & $\begin{array}{l}\text { Average } \\
\text { Calorific } \\
\text { Value (TJ/Gg) }\end{array}$ \\
\hline 010506 & $3.161,38$ & 9,83 & 080121 & 10,25 & 15,18 & 150202 & $6.220,15$ & 13,32 \\
\hline 020303 & 698,34 & 15,65 & 080312 & 35,60 & 4,60 & 150203 & 157,44 & 18,46 \\
\hline 020304 & $1.402,90$ & 12,91 & 080314 & 176,57 & 9,89 & 160103 & $129.216,48$ & 24,44 \\
\hline 020305 & 4,12 & 10,47 & 080317 & 0,38 & 13,80 & 160119 & 2,15 & 15,60 \\
\hline 020502 & 0,60 & 10,47 & 080409 & 134,30 & 12,88 & 160306 & 7,05 & 15,18 \\
\hline 020701 & $1.029,30$ & 0,00 & 100101 & 676,94 & 1,49 & 160708 & 144,30 & 24,83 \\
\hline 020705 & 926,50 & 11,74 & 100102 & 70,82 & 2,09 & 160709 & 18,50 & 12,61 \\
\hline 030105 & 6,60 & 15,60 & 110109 & 37,80 & 16,62 & 170204 & 452,76 & 11,77 \\
\hline 030307 & $17.161,25$ & 12,86 & 120105 & 306,05 & 15,39 & 170503 & $2.101,22$ & 4,80 \\
\hline 030308 & 192,86 & 12,60 & 120107 & 27,00 & 19,40 & 170604 & 25,10 & 14,49 \\
\hline 030311 & 912,55 & 11,74 & 120109 & 21,16 & 14,28 & 190205 & $3.196,79$ & 9,02 \\
\hline 040219 & 126,70 & 1,66 & 120112 & 7,68 & 20,70 & 190207 & 10,05 & 3,53 \\
\hline 040221 & 22,35 & 15,18 & 120114 & 2,30 & 14,28 & 190209 & $16.797,70$ & 15,18 \\
\hline 040222 & $8.784,64$ & 13,31 & 120116 & 106,65 & 14,55 & 190805 & $142.834,38$ & 8,84 \\
\hline 050103 & $8.968,74$ & 17,67 & 120118 & 250,30 & 9,69 & 190811 & $1.081,35$ & 10,54 \\
\hline 050105 & $4.162,61$ & 6,94 & 130110 & 3,05 & 23,20 & 190812 & 102,60 & 12,01 \\
\hline 050106 & 27,56 & 6,27 & 130111 & 1,30 & 29,30 & 190813 & $18.583,17$ & 6,34 \\
\hline 050109 & 899,75 & 11,14 & 130113 & 60,87 & 26,78 & 190814 & 890,35 & 7,59 \\
\hline 050115 & 5,10 & 14,55 & 130205 & 43,81 & 29,97 & 190904 & 4,54 & 8,37 \\
\hline 061302 & 11,30 & 23,00 & 130208 & $3.275,45$ & 29,62 & 190905 & 23,05 & 15,18 \\
\hline 070112 & $1.755,03$ & 2,09 & 130310 & 9,65 & 33,49 & 191201 & 188,86 & 13,00 \\
\hline 070204 & 3,35 & 15,18 & 130403 & $1.421,91$ & 22,11 & 191204 & $2.112,08$ & 15,72 \\
\hline 070208 & 30,42 & 6,93 & 130502 & 434,71 & 12,57 & 191210 & $11.670,25$ & 12,81 \\
\hline 070211 & 13,40 & 0,91 & 130506 & 297,68 & 27,29 & 191211 & $254.884,74$ & 12,74 \\
\hline 070213 & $4.020,76$ & 16,57 & 130508 & $8.726,20$ & 27,36 & 191212 & $30.451,22$ & 10,95 \\
\hline 070214 & 230,19 & 16,79 & 130701 & $1.515,96$ & 30,41 & 191305 & 24,90 & 6,29 \\
\hline 070217 & 114,14 & 15,52 & 130703 & $13.109,67$ & 25,35 & 200101 & $13.323,26$ & 15,18 \\
\hline 070608 & 1,22 & 4,60 & 150101 & 36,75 & 15,60 & 200111 & $12.030,53$ & 14,16 \\
\hline 070708 & 31,54 & 2,54 & 150102 & $1.519,76$ & 14,94 & 200127 & 0,36 & 8,40 \\
\hline 080111 & 8,25 & 15,18 & 150103 & 95,20 & 15,18 & 200138 & 20,95 & 15,18 \\
\hline 080112 & 47,92 & 14,28 & 150105 & 405,75 & 15,39 & 200139 & $7.706,75$ & 14,11 \\
\hline 080113 & 760,33 & 13,33 & 150106 & $15.413,56$ & 14,42 & & & \\
\hline 080114 & 12,76 & 4,60 & 150110 & 58,54 & 15,51 & & & \\
\hline
\end{tabular}




\section{Conclusion}

There were various options for supplying energy by alternative ways for enhancing energy necessity. In this way, the use of waste as an energy source was the solution for industrialists to provide more cost-effective and uninterrupted energy. Waste minimization and reduction in energy imports, the use of waste as a supplementary fuel were the pillars of sustainable energy supply in the cement industry. Energy recycling from waste played an active role in establishing policies to meet the continuous, high quality and costeffective energy needs of the industry. Coprocessing waste in cement production had economic and environmental benefits by decreasing energy costs.

The design and interior of cement kilns create an ideal environment for the incineration of waste with conventional fuels. Cement rotary kiln provided full combustion of waste and no extra stoichiometry with an oxidizing environment, long retention time during clinkerzation. Acid gases, sulfur oxides and hydrogen chloride were fully neutralized by the active lime that is fed into kilns. Heavy metals in hazardous waste were bonded as metallic silicates in clinker. There was no ash problem after combustion. Thus, the environmental effects of waste were prevented. This meant less storage space requirement with reduced amount of hazardous waste.

Conservation of natural resources was facilitated by using waste instead of nonrenewable fuels and resource management is too.

It is necessary to increase the permissible utilization rate of $40 \%$ of thermal power in order to encourage and support the cement industry to supply energy more cost- effectively within the scope of waste utilization license.

If the grain size, chlorine amount, moisture and calorific value of the waste are provided with the correct mixing ratio in the feed of the waste in the kilns, there is no negative effect on the clinker quality and emissions and the target is achieved in energy recovery and economic gains. The kilns technology is safety for processing waste in environmental perspective.

Symbiotic network should be established to ensure a regular supply of waste. The training courses and seminars should be provided for industrialists.

There will be no requirement for disposal and incineration facilities for waste by using the waste as alternative fuel in cement industry.

Waste disposal can be carried out and greenhouse emissions caused by waste incinerators can be prevented by using waste instead of fossil fuels in the cement industry. Waste should be used instead of coal to reduce the amount of greenhouse gas emissions during the cement production. Greenhouse gas emissions arising from any new incinerators and storage in landfills will also be prevented. The present study is first ever conducted in a developing country as Turkey. The study would be numerical value of sustainability in cement industry in real scale. The study will lead researches about waste use recycling gains.

\section{Acknowledgements}

Turkey Cement Manufacturers' Association is acknowledged for information support. 


\section{References}

1. European Cement Research Academy (ECRA) GmbH, A-2016/1039. Duesseldorf, Germany, TR 044/2007 (2016) 7. Retrieved from https://docplayer.net/143212686-

European-cement-researchacademy.html

2. Türkiye Çimento Müstahsilleri Birliği İstatistik Raporları (TCMB), (2018) Ankara. Retrieved from https://www.tcma.org.tr/tr/istatistikler/ay lik-veriler

3. T. C. Çevre ve Şehircilik Bakanlığı (CSB) Çimento Sanayi İçin Mevcut En İyi Teknikler (MET) Ulusal Kilavuzu, Ankara (2016). Retrieved from

https://webdosya.csb.gov.tr/db/ippc/iceri kler/ulusal-met-kilavuzu20180425132410.pdf.

4. J. S. Damtoft, J. Lukasik, D. Herfort, D. Sorrentino and E. M. Gartner, Cem. Concr. Res., 38 (2008) 115.

5. K. T. Kaddatz, M. G. Rasul and A. Rahman, Procedia Eng., 56 (2013) 413. https://doi.org/10.1016/j.proeng.2013.03. $\underline{141}$

6. N. A. Madlool, R. Saidur, M. S. Hossain and N. A. Rahim, Renew. Sust. Energ. Rev., 15 (2011) 2042.

https://doi.org/10.1016/j.rser.2011.01.00 $\underline{5}$

7. M. B. Ali, R. Saidur and M. S. A. Hossain, Renew. Sust. Energ. Rev., 15 (2011) 2252.

https://doi.org/10.1016/j.rser.2011.02.01 $\underline{4}$

8. O. Ekincioglu, A. P. Gurguna, Y. Engin, M. Tarhan and S. Kumbaracibasi, Energ. Buildings, 66 (2013) 136.

https://doi.org/10.1016/j.enbuild.2013.07 .006 .

9. U. Kaantee, R. Zevenhoven, R. Backman and M. Hupa, Fuel Proces. Technol., 85 (2004) 293. Retrieved from http://www.sciencedirect.com/science/article /B6TG3-49MF16K2/2/166abe8db286b9e23389c46fbd53d2f0

10. B. Reza, A. Soltani, R. Ruparathna, R. Sadiq and K. Hewage, Resour. Conserv. Recycl., 81 (2013) 105.

https://doi.org/10.1016/j.resconrec.2013. $\underline{10.009}$

11. N. Chatziaras, C. S. Psomopoulos and N. J. Themelis, 12th International Conference on Protection and Restoration of the Environment Conference, 1 (2014) 521. Retrieved from

https://www.researchgate.net/publication /263714046_Use_of_alternative_fuels_i n_cement_industry

12. A. Bourtsalas, J. Zhang, M. Castaldi and N. Themelis, J. Clean. Prod., 181 (2018) 8.

doi: 10.1016/j.jclepro.2018.01.214.

13. C. A. Tsiliyannis, J. Ind. Ecolog., 22 (2017) 5.

https://doi.org/10.1111/jiec.12644

14. GTZ-Holcim Public Private Partnership, Guidelines on Co-processing Waste Materials in Cement Production, Dt. Ges für Technische Zusammenarbeit (GTZ), Germany (2006). Retrieved from https://www.geocycle.com/sites/geocycl e/files/atoms/files/coprocessing_supporting_document_gizholcim_guidelines_0.pdf

15. M. Georgiopoulou and G. Lyberatos, $J$. Environ. Manage., 216 (2018) 224.

https://doi.org/10.1016/j.jenvman.2017.0 $\underline{7.017}$

16. J. Karagiannis, C. Ftikos and P. Nikolopoulos, WIT Trans. Ecol. Environ., 109 (2008) 105. doi: 10.2495/WM080121

17. M. Schneider, M. Romer, M. Tschudin and H. Bolio, Cem. Concr. Res., 41 (2011) 642.

http://doi.org/10.1016/j.cemconres.2011. $\underline{03.019}$ 
18. H. Mikulčić, J. Klemeš, M. Vujanović, K. Urbaniec and N. Duić, J. Clean. Prod., 136 (2016) 119. doi: 10.1016/j.jclepro.2016.04.145

19. M. Kara, Resour. Conserv. Recycl., 68 (2012) 21.

https://doi.org/10.1016/j.resconrec.2012. 06.011

20. MPM Chinyama, In: Manzanera M (ed). Intech Europe, Croatia. ISBN: 978-953307-372-9 $11 \quad$ (2011) 263 Available from:http://www.intechopen.com/books/ alternative-fuel/alternative-fuels-incement-manufacturing http://doi.org/10.5772/22319

21. European Commission Best Available Techniques (BAT) Reference Document for the Production of Cement, Lime and Magnesium Oxide, Industrial Emission Directive 2010/75/EU Integrated Prevention and Pollution Control. Publications Office of the European Union. Seville, Spain (2013). http://dx.doi.org/10.2788/12850

22. E. Mokrzycki and A. UliaszBochenczyk, Appl. Energ., 74 (2003) 95. http://doi.org/10.1016/S03062619(02)00135-6.

23. B. Iglinski and R. Buczkowski, J. Clean. Prod., 141 (2017) 702.

https://doi.org/10.1016/j.jclepro.2016.09. $\underline{139}$

24. A. Rahman, M. G. Rasul, M. M. K. Khan and S. Sharma, Fuel, 145 (2015) 84.

http://doi.org/10.1016/j.fuel.2014.12.029

25. M. Naranjo, D. T. Brownlow and A. Garza, Energ. Procedia, 4 (2011) 2716. Retrieved from https://core.ac.uk/download/pdf/8260265 $\underline{\text { 5.pdf }}$

26. G. Stefanovic', G. Vuc;kovic', M. Stojiljkovic' and M. Trifunovic', Therm. Sci., 14 (2010) 671. doi: 10.2298/TSCI091211014S
27. E. Benhelal, G. Zahedi, E. Shamsaei and A. Bahadori, J. Clean. Prod., 51 (2013) 142.

https://doi.org/10.1016/j.jclepro.2012.10. $\underline{049}$

28. L. A. Tokheim, T. Gautestad, E. P. Axelsen and D. Bjerketvedt, International Symposium on Incineration and Flue Gas Treatment Technologies, 3 (2001) 1.Retrieved from http://hdl.handle.net/11250/2438520

29. J. Deja, A. Uliasz-Bochenczyk and E. Mokrzycki, Int. J. Greenh. Gas Control, 4 (2010) 583. Retrieved from http://doi.org/10.1016/j.ijggc.2010.02.002

30. R. Kajaste and M. Hurme, J. Clean. Prod., 112 (2016) 4041. doi: 10.1016/j.jclepro.2015.07.055

31. The European List of Waste (Commission Decision 2000/532/EC, Annex - List of Waste Referred To In Article 7 Of Directive 2008/98/EC.

32. Atıkların Yakılmasına İlişkin Yönetmelik, T. C. Resmi Gazete, 6 (2010) 27721. Retrieved from https://www.mevzuat.gov.tr/mevzuat?M evzuatNo $=14344 \&$ MevzuatTur $=7 \& \mathrm{Mev}$ zuatTertip $=5$

33. Türkiye Çimento Müstahsilleri Birliği, İstatistik Raporları, Ankara (2019). Retrieved from https://www.tcma.org.tr/tr/alternatif_yak it_ve hammaddeler

34. Intergovernmental Panel on Climate Change (IPCC) Guidelines for National Greenhouse Gas Inventories Technical Support Unit of the IPCC National Greenhouse Gas Inventories Programme, Kyoto (2006). Retrieved from https://www.ipcc.ch/report/2006-ipccguidelines-for-national-greenhouse-gasinventories/ 